\title{
Ecosystem services: a means to diffuse political land use decisions in peri-urban regions
}

\author{
J. A. Williams ${ }^{1,2}$ \& P. V. Martin ${ }^{1,2}$ \\ ${ }^{1}$ University of New England, Australia \\ ${ }^{2}$ Cooperative Research Centre for Irrigation Futures, Australia
}

\begin{abstract}
Research undertaken to advance sustainable land-use in peri-urban Australia has identified the need for greater innovation in natural resource management (NRM). This requires moving from an overly regulation-dependent resource management system to an environmental market system. Under current arrangements, continued resource depletion and degradation; institutional barriers to innovative solutions, and high transaction costs in affecting change are all evident. An environmental markets policy approach would shift emphasis to a market economy and facilitate commercial innovation in the use and conservation of resources. This requires first that the environmental goods and services (or commodities) be clearly identified; and second a market structure to enable trade. Martin et al (Concepts for private sector funded conservation using tax effective instruments Land and Water Australia, Canberra 2007) have proposed a business model for natural resource markets using a multi-attribute, low transaction cost environmental market structure. However to develop such a model requires a consistent methodology and classification system to identify ecosystem services as viable commodities, for 'marketizing' these multiple values. A conceptual framework for identifying and valuing ecosystem services is presented using Western Sydney as a case study. The paper also argues that a science informed rather than a science led process may be a more realistic ambition for natural resource management in peri-urban Australia.
\end{abstract}

Keywords: natural resource management, ecosystem services, political economy, market based systems, transaction costs, innovation.

\section{The need for peri-urban environmental markets}

Recent research in peri-urban Australia [1] has identified the need for greater innovation in NRM and the over-reliance on regulation and the absence of 
environmental services markets. South Creek, Western Sydney, the case study region, lies within the Sydney peri-urban riverine system. This region continues to experience ongoing environmental degradation and water shortages as a result of urban development, population demand and climate change [3,4]. Collaborative research [5] to address these issues has found the fundamental dominance of political economy, over both science and economics, to be a significant impediment to improvement. The Sydney peri-urban riverine system, generally assumed to be a natural system adjusted by human intervention is in reality an industrial system that delivers some natural values, with its operation determined by politics. Politics sets narrow boundaries within which science can be deployed and innovations may be achieved. Political decision-making creates institutional barriers and high transaction costs when attempts are made to enhance environmental or economic values. An alternative approach would be to engage markets for environmental values, which should be more conducive of innovation than the current regulatory model. An environmental services market may expand the range of natural services that can achieve economic value and increase the potential that natural resources will be given a higher priority in decisions. However, to develop the policy framework for such a market requires that environmental services be clearly identified and that a market structure be adopted which can be competitively vibrant. Australia has experimented with the trading of ecosystem services with mixed results [6]. There are gaps in knowledge about the condition of the natural resource base due to inconsistent indicators [7] and inconsistencies in ecosystem service classification [8]. Martin et al [2] have proposed a structure for a market to increase private conservation investment for landscape-scale management. This consists of an investment program operated through a trust involving philanthropic and research funds, and an ecosystem services managed investment scheme. To move to any such model will require policy change and the creation of economic opportunity. This requires the identification and valuation of the ecosystem services, which might be traded.

This paper has two aims:

(i) To address the identification of ecosystem services, by distinguishing the environmental commodities available from this peri-urban environment. This is a conceptual framework for identifying and valuing ecosystem services in the case study region, and

(ii) To demonstrate how a 'science informed' market process (rather than an unattainable science-led approach) can help diffuse political impediments to better natural resource management in a highly politicised environment.

\section{Description of the case study region}

South Creek, Western Sydney is situated within the Greater Sydney region in the state of New South Wales (NSW), Australia (see Figure 1). It is a sub-catchment of the Hawkesbury Nepean River, which flows for over 64 kilometres and together with Eastern Creek forms a major drainage basin [3]. South Creek encompasses most of the Cumberland Plain of Western Sydney [4] (consisting of 
low-lying gently undulating plains and low hills). This sub-catchment is the most degraded of the catchment system [3,4]. South Creek has environmental, social and economic values $[4,9,10,11]$ delivered through a mosaic of land-uses from an already degraded landscape. With a growing human population comes pressure on the services they provide.

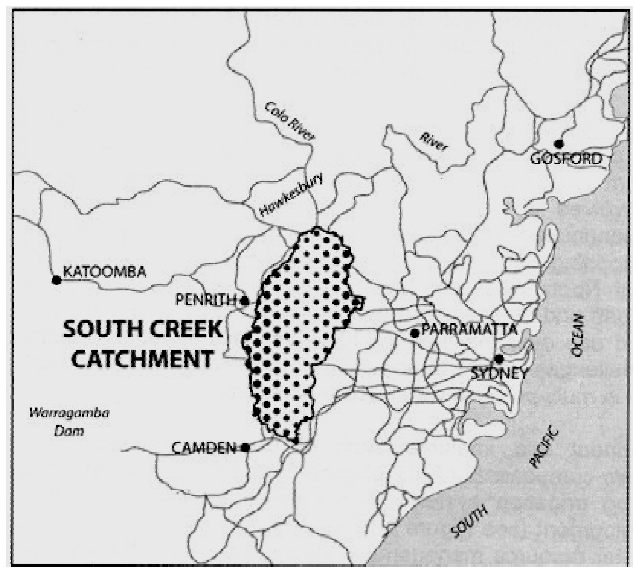

Figure 1: $\quad$ Map of case study region [3].

South Creek is a case study region for the Cooperative Research Centre for Irrigation Futures (CRCIF) with the research aiming for a 'harmonized' approach to sustainable use of land and water. The System Harmonization program involves four research projects addressing water cycle management; markets and productivity; social, cultural, institutional and policy frameworks (SCIP), and integration. The program aims to use science to improve management of surface and groundwater resources [5]. It is predicated on the rational expectation that water management ought be based on scientific hydrological modeling. In practice natural resource consumption occurs within a framework of economic, political and institutional structures, with different drivers. The limits of science to shape resource management decisions are demonstrated in peri-urban regions where scientific recommendations become submerged by political considerations.

To understand resistance to scientific innovation the researchers undertook detailed institutional analysis of Western Sydney exploring the interactions between the biophysical, economic and institutional aspects that drive natural resource consumption. The methodology focused on transactions between people and the environment, and between people (a coupled systems conceptualisation). Qualitative research undertaken during 2007 and 2008 [1] found that the application of scientifically or economically rational models for NRM is frustrated by institutional impediments, high transaction costs and political constraints on innovation. These include: 
- Complexity associated with a large number of regulations, market instruments and organizations;

- The political and administrative interests associated with these arrangements, and the power associated with control of information and natural resources as property;

- Impediments to obtaining mandatory licenses, or alterations to planning and administrative arrangements, and

- Conflict from institutional competition and the absence of effective coordinating mechanisms.

To resolve resource use problems within the existing model (which makes politician considerations paramount) would be difficult. It is a principle of resource economics that attaching economic value to natural resources makes it more likely that conservation or restoration of these now 'marketized' values will occur. To achieve a market for these values requires viable non-government buyers and sellers of ecological values who can drive a revaluation of these resources. Economic value is needed as the basis for commercial gain. The following discussion provides an overview of the potential business model for a vibrant ecosystem service market, and an approach to identification of potentially marketized services, which could be the basis for the required transactions.

\section{A potential market model}

Three impediments for viable environmental investment markets have been recognised: the insufficiency of ecosystem service markets generally, the political constraints on conservation strategies, and the taxation treatment of conservation investments [2]. Martin et al [2] propose a model that combines philanthropy, commercial markets and taxation arrangements, which is consistent with private ownership and investment. This places responsibility, authority and resources with private landowners who currently manage $>60 \%$ of the natural resource base in Australia [12]. The business model proposes commercial accountability for conservation outcomes and aims to attract private philanthropic and commercial funds into conservation investments delivering ecosystem services through multiple land uses. It reflects existing institutional structures with a trust managed by professional funds managers, which would operate three subordinate funds being the philanthropic and research funds, and the ecosystem service managed investment scheme. A tax-supported managed investment approach is recommended to counter the disincentive effect of the uncertainty of returns from emerging environmental markets. The business model relies on a regional collective of natural resource managers (predominantly landowners and other interest groups) for the delivery of ecosystem services to investors of the trust. To advance such a model requires a methodology to identify the ecosystem services for viable trading, so that markets for these can be proposed and implemented. This paper proposes a framework for doing so using a consistent methodology and classification system to identify ecosystem services as potential commercial commodities. 


\section{Ecosystem services methodology}

The Millennium Ecosystem Assessment [13] provides a nine step analytical approach to identify and value ecosystem services:

i. Identify and categorise ecosystems and ecosystem services;

ii. Identify the links between human societies and ecosystem services;

iii. Identify direct and indirect drivers;

iv. Assess conditions and trends of ecosystems and their services;

v. Assess impact on human well-being;

vi. Develop scenarios;

vii. Analyse response options, and

viii. Analyse uncertainty

A variety of approaches to identify and value ecosystem services [8] have evolved [14-21]. Signposts for Australian Agriculture [22] adopted the Millennium Ecosystem Assessment [13] classes of with the notable addition of the capacity to provide biodiversity conservation services in its own right due to it's significance within Australia's legislation and policies [22].

\subsection{Definitions}

There is some disagreement [23] about these evolving concepts. Wallace [8] recently identified that ecosystem service classification suffers from combining processes (means) for achieving services and the services themselves (ends). System Harmonization, which involves the integration of disciplines, has forced the researchers to tackle this ambiguity. Wallace [8] provides the definitions used in this discussion. These definitions are:

- Ecosystem is defined as a functional entity or unit formed locally by all the organisms and their physical (abiotic) environment interacting with each other with this definition including both culturally derived and natural elements;

- Ecosystem elements are defined as tangible entities that are both natural and cultural and described in the terms of amount;

- Ecosystem processes are defined as the complex interactions (events, reactions or operations) among biotic and abiotic elements of ecosystem services that lead to a definite result such as the transfer of energy and materials. These processes are generally described in terms of rates;

- Ecosystem function, which is also often used in the literature, is considered a synonym of 'ecosystem process';

- Ecosystem services are defined as the benefits people obtain from natural and cultural elements of ecosystems including provisioning services; regulating services; cultural services, and supporting services, and

- Human values are defined as the preferred end-states of existence for human wellbeing.

Peri-urban refers to the lands which fringe metropolitan areas, consisting of a mosaic of urban, agricultural, rural residential, recreational and conservation land uses. The Millennium Ecosystem Assessment [13] nine-step analytical process has similarities to the System Harmonization approach where the hydrological 
cycle is categorised and the services identified; the direct and indirect institutional drivers of transactions are identified; the impacts on the environment are to be identified through markets and products, and the link between society and the water cycle and the impacts of different scenarios are to be explored. What is being developed is a method to incorporate the human values placed on the ecosystems, as potential market values.

\section{Designing the ecosystem services framework}

An ecosystem services framework has been developed to integrate economic; social/cultural; hydrological and markets/production disciplines (see Figure 2).

\subsection{Model based service valuation methods}

The ecosystem services framework uses models and Geographical Information Systems (GIS) to assist in identifying, categorising and valuing ecosystem services. Alberti et al [24] claim that biophysical and human agents drive the urban socio-economic and biophysical patterns/ processes that control ecosystem functions. Traditional land use planning is considered as failing to include the valuation of public good ecosystem services [25], as in Western Sydney.

Recent research [26] has attempted to efficiently value ecosystem goods and services by modelling linked to valuation methods using a GIS platform to provide clear identification of natural assets that produce these services, and the cadastral and property ownership dimension needed as a basis for tradeable entitlements. A decision framework linking GIS and value transfer to ecosystem services was used to estimate ecosystem service flow values to map results of three case studies in America [27]. The System Harmonization program in Western Sydney was designed to comprise hydrological models; GIS layers; economic modelling; markets and products; scenario development, and social/cultural/institutional/economic analysis. What has now been identified is that these elements can be used to identify ecosystem services, and that science can lead the reconsideration of the fundamentals of land use and water policy (notably the potential for markets to supplement or replace regulation, and enable innovations in resource management). GIS layers can be populated from data collected through the ecosystem services framework and used in scenario exploration of future land use decisions to demonstrate the trade offs, costs and benefits of decisions affecting ecosystem services. However, for such an approach to be effective there needs to be a method to translate broad-scale land forms into specific values.

\subsection{Identifying the specific values within the landscape}

The Sydney Basin is one of 85 bioregions within Australia [28]. Western Sydney is within the Cumberland sub-region [29] of the bioregion. Western Sydney lies within the Hawkesbury-Nepean Catchment, covering 2.2 million hectares and flowing some 470 kilometres. Mosaics of landforms are best classified using elements identified by the physical appearance of a slope, and typical landform 


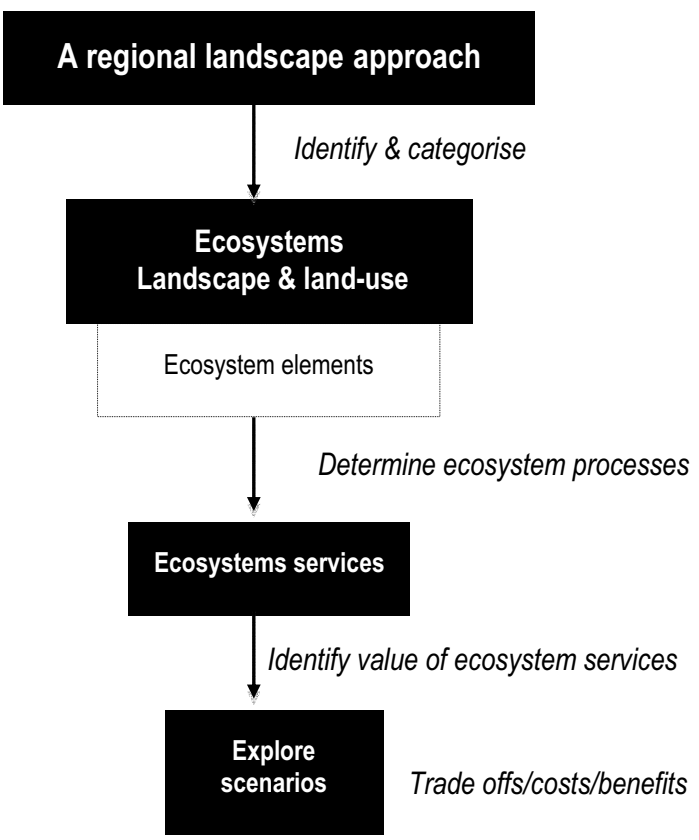

Figure 2: $\quad$ Ecosystem services framework for peri-urban Australia.

elements in natural resource assessment include: crests; hillslopes; footslopes; floodplains; drainage depressions; disturbed terrain, and water bodies [30]. Western Sydney ecosystem element classification is based on these standard landform elements with disturbed terrain (categorised as both urban and agriculture) and tidal estuaries included as a special category given the influence of the sub-catchment on the estuaries of the Hawkesbury River. These ecosystem elements can be further described through: topographical typology; slope classes; geology and soils classification; vegetation cover; biodiversity, and water body assessment all of which would require the use of consistent methodologies and definitions following national standards [30-38]. The Millennium Ecosystem Assessment [13] has established a classification for the types of ecosystem services and the processes that underpin these services. Signposts for Australian Agriculture [22] and many other authors [8,15,20,39] recognise this classification system. Wallace [8] defined ecosystem elements as tangible entities that are both natural and cultural and best described quantitatively; whereas ecosystem processes are defined as the complex interactions amongst biotic and abiotic elements that lead to a definite result. These are best described in terms of rates. Ecosystem services for Western Sydney can be identified by determining the ecosystem processes of the Western Sydney ecosystem elements and attaching to these the benefits people obtain from these. Tables 1 and 2 provide a classification system to guide this identification process. 
Table 1: $\quad$ Ecosystem elements of South Creek, Western Sydney [30].

\begin{tabular}{|l|l|l|l|l|l|l|l|l|}
\hline \multicolumn{2}{|c|}{ South Creek Ecosystem elements } \\
\hline \multirow{2}{*}{ Crests } & $\begin{array}{l}\text { Hill } \\
\text { slopes }\end{array}$ & $\begin{array}{l}\text { Foot } \\
\text { slopes }\end{array}$ & $\begin{array}{l}\text { Flood } \\
\text { plains }\end{array}$ & $\begin{array}{l}\text { Drainage } \\
\text { Depressions }\end{array}$ & $\begin{array}{l}\text { Water } \\
\text { bodies }\end{array}$ & $\begin{array}{l}\text { Tidal } \\
\text { Estuaries }\end{array}$ & \multicolumn{2}{|c|}{ Land use } \\
& & & & Urban & Agriculture \\
\hline
\end{tabular}

Table 2: $\quad$ Ecosystem services and processes classification [13].

\begin{tabular}{|c|c|c|c|}
\hline \multicolumn{4}{|c|}{ Ecosystem Services } \\
\hline $\begin{array}{l}\text { Supporting services } \\
\text { through the processes of: } \\
\text { - } \quad \text { Soil formation } \\
\text { - Photosynthesis } \\
\text { - } \quad \text { Primary production } \\
\text { - Nutrient cycling } \\
\text { - } \quad \text { Water cycling }\end{array}$ & $\begin{array}{l}\text { Provisioning Services } \\
\text { through the processes } \\
\text { of: } \\
\text { - } \quad \text { Food \& fibre } \\
\text { production } \\
\text { - Genetic resources } \\
\text { - Bio-chemical, } \\
\text { natural medicines } \\
\text { etc } \\
\text { - Ornamental } \\
\text { resources } \\
\text { - } \quad \text { Fresh water }\end{array}$ & $\begin{array}{l}\text { Regulating Services } \\
\text { through the processes } \\
\text { of: } \\
\text { - } \quad \text { Air quality } \\
\text { - } \text { regulation } \\
\text { - } \quad \text { Climate regulation } \\
\text { - } \quad \text { Erosion regulation } \\
\text { - } \quad \text { Disease } \\
\text { - } \text { regulation } \\
\text { - } \quad \text { Pest regulationation }\end{array}$ & $\begin{array}{l}\text { Cultural Services } \\
\text { through the processes } \\
\text { of: } \\
\text { - } \quad \text { Cultural diversity } \\
\text { - } \quad \text { Spiritual \& } \\
\text { religious values } \\
\text { - } \quad \text { Recreation and } \\
\text { ecotourism } \\
\text { - } \quad \text { Aesthetic values } \\
\text { - } \quad \text { Knowledge } \\
\text { - } \text { systems } \\
\text { - Education } \\
\text { systems }\end{array}$ \\
\hline
\end{tabular}

\subsection{Linking ecosystem values to landscape and waterscape elements}

Western Sydney region has environmental significance with $50 \%$ of the area protected through National Parks and reserves and high biodiversity values recognised nationally and internationally significant. Culturally the region is rich with $15.6 \%$ of the NSW aboriginal communities.

The catchment has social significance supporting a population of 1 million; providing drinking water for over 4 million people of the region; supporting 43,000 recreational fishers, and supplying water to produce $70 \%$ of NSW's goods and services. Economically the catchment is significant. Irrigated agriculture is valued at $\$ 1$ billion per year to the farmer and $\$ 4.5$ billion to the industry as a whole [10]. Public open space for Greater Sydney region represents an avoided cost between $\$ 10.6 \mathrm{M}$ and $\$ 14.6 \mathrm{M}$ per year [11]. Valuation of activities dependent on the Hawkesbury Nepean River [9] found recreation and tourism have an estimated economic value of $\$ 93.7$ million per annum; irrigated agriculture with an estimated annual economic value of $\$ 10.6$ million and commercial fishing/oyster production with an estimated value of $\$ 1$ million Despite these high values the catchment is facing challenges due to the rapidly growing population [4]. Qualitative research undertaken in Western Sydney [40] identified agriculture, open space, water quality and biodiversity as high values sought by stakeholders.

A number of studies [41-45] point the way to attach social and economic value to rural land-uses, using methods that could be adapted to indicate 
available ecosystem services in Western Sydney, using spatially identified landforms rather than other more costly methods. What these studies demonstrate is the potential to use landform, and water through the landform, as an indicator of the ecosystem services provided (or available). Application in a peri-urban setting is likely to provide fresh insights into the contribution made by natural features and services to the economy and society of these regions. Attaching valuation, and making these values spatially attributable, should also assist in identification of the potential counter-parties for trade in a future market. This raises the question 'how can the link be drawn between spatially located environmental service assets, and a dollar value?' In our consultations in Western Sydney, a concern has frequently been raised that existing management approaches to water and land fail to value the full range of the ecosystem services [40]. These consultations suggest that there is an under-recognition of the value of agriculture; water quality; open space and biodiversity in the current land use decision making process. Methods to better value ecosystem services in Australia exist [46-51] that can be adapted to determine the non-economic values of the region, and provide the empirical basis for justifying the shift towards establishment of an environmental market.

\section{Conclusion}

The CRCIF System Harmonization research in Western Sydney was based on the assumption that science-led, model-based policy proposals would have a reasonable chance of being accepted. However, implementation of modelling in the regulatory/political system of Western Sydney has found that there is little space for science that suggests conclusions which conflict with political imperatives. Therefore, to make space for the innovations that science or economics could suggest are desirable requires an 'environmental services market' logic, to elevate the importance of these values in policy making. Creating a viable environmental services market for investment in natural resources is a credible way to do so. To achieve a shift to this alternative policy framework necessitates proof to both commerce and government of the ecosystem services delivered and the social effects of a peri-urban environmental services market. It also requires clear evidence that there will be the potential for a vibrant market. A coupled systems approach as utilised in Western Sydney provides a means to qualify and precisely identify ecosystem services values; their position in the landscape; the ownership and control of these services, and where they might fit within the landscape planning structures that currently exist. Whilst there are many challenges facing peri-urban Australia in the valuation and protection of agriculture, open space, water quality and biodiversity, this paper proposes some directions that could be used to efficiently resolve the identification and valuation problem and open up possibilities of a peri-urban environmental services market. GIS plays a more important role in this approach than was originally envisaged. 


\section{References}

[1] Martin, P.V; Williams, J.A; Stone, C; Transaction costs and water reform: the devils hiding in the detail Technical Report No.08/08 Cooperative Research Centre for Irrigation Futures Australia 2008.

[2] Martin, P.V; Werren, K; Shearing, S; Concepts for private sector funded conservation using tax effective instruments Land and Water Australia, Canberra 2007.

[3] Rae, D. J. Water Management in South Creek Catchment: current state, issues and challenges Technical Report 12/07 Cooperative Research Centre for Irrigation Futures Australia 2007.

[4] Hawkesbury Nepean Catchment Management Authority Hawkesbury Nepean River Health Strategy Hawkesbury Nepean Catchment Management Authority Goulburn 2008.

[5] Cooperative Research Centre for Irrigation Futures System Harmonization Integration and RIBPs http://www.irrigationfutures.org.au /projects.asp?ID=36 2009.

[6] Whitten, S.M; Coggan, A; Reeson, A; Gorddard, R Putting theory into practice: market failure and market based instruments (MBIs) CSIRO Canberra 2007.

[7] Beeton, R.J.S; Buckley Kristal I; Jones Gary J; Morgan Denise; Reichelt Russell E \& Trewin Dennis (2006 Australian State of the Environment Committee) Australia State of the Environment Independent report to the Australian Government Minister for the Environment and Heritage, Department of the Environment and Heritage, Canberra 2006.

[8] Wallace, K; "Classification of ecosystem services: Problems and solutions.” Biological Conservation 139: 235-246, 2007.

[9] AgEconPlus; Quantifying the Economic Value of Activities Dependent on the Hawkesbury-Nepean River AgEconPlus Sydney 2006.

[10] Gillespie, P. \& Mason, D; Sydney Basin Industry Details NSW Agriculture, Orange 2003.

[11] Sydney Urban Parks Education and Research Group; The Value of Public Open Space for Community Service Provision Sydney Urban Parks Education and Research Group Sydney 2001.

[12] Bureau of Rural Science Land use at a glance Bureau of Rural Science Canberra 2006.

[13] Millennium Ecosystem Assessment; Ecosystems and human wellbeing: a framework for assessment Island Press Washington DC 2003.

[14] Costanza, R; D’Arge, R; De Groot, R; Farber, S; Grasso, M; Hannon, B; Limburg, K; Naeem, S; O’Neill, R; Paruelo, J; Raskin, R.G; Sutton, P; Van Den Belt, M; "The values of the world's ecosystem services and natural capital." Nature 387: 253-260. 1997.

[15] Chee, Y. E; "An ecological perspective on the valuation of ecosystem services.” Biological Conservation 120: 549-565 2004.

[16] Millennium Ecosystem Assessment; Ecosystems and Human Well-being World Resources Institute Washington DC 2005. 
[17] Abel, N; Cork, S; Gorddard, R; Langridge, J; Langston, A; Plant, R; Proctor, W; Ryan, P; Shelton, D; Walker, B; Yialeloglou, W; Natural Values: Exploring options for enhancing ecosystem services in the Goulburn-Broken Catchment CSIRO Sustainable Ecosystems Canberra 2003.

[18] Binning, C., Cork, S., Parry, R., Shelton, D; Natural assets: An inventory of ecosystem goods and services in the Goulburn Broken catchment CSIRO Canberra 2001

[19] Reid, N; O'Shea, G; Silberbauer, L; A review of biodiversity research in the Australian Cotton Industry Final Report to the Cotton Research and Development Corporation University of New England Armidale 2003.

[20] De Groot, R; "Function-analysis and valuation as a tool to assess land use conflicts in planning for sustainable, multi-functional landscapes." Landscape and Urban Planning 75: 175-186 2006.

[21] Peterson, G.D; Beard Jnr, T.D; Beisner, B.E; Bennett, E.M; Carpenter, S.R; Cumming, G.S; Dent, C.L; Havlicek, T.D; "Assessing future ecosystem services: a case study of the Northern Highlands Lake District" Conservation Biology 7(3): 12003.

[22] Bureau of Rural Sciences \& Department of Agriculture, Forestry and Fisheries Australia; Ecosystem services http://signposts4ag.com/signpostsgrains/glossary/ecosystem-services/ 2008.

[23] Davidson, B; Mushtaq, S; Simmons, B; Allan, C; Regan, P; Understanding and valuing the economic, social and environmental components of System Harmonisation Cooperative Research Centre for Irrigation Futures Technical Report No. 13/07 Australia 2007.

[24] Alberti, M; Marzluff, J.M; Shulenberger, E; Bradley, G; Ryan, C; Zumbrunnen, C; "Integrating Humans into Ecology: Opportunities and challenges for Studying Urban Ecosystems." BioScience 53(12): 116911792003.

[25] Productivity Commission Annual Review of Regulatory Burdens on Business Commonwealth of Australia Melbourne 2007.

[26] Gret-Regamey, A; Bebi, P; Bishop, I.D; Schmid, W.A; "Linking GIS-based models to value ecosystem services in an Alpine region." Journal of Environmental Management 89: 197-208 2008.

[27] Troy, A. and M. Wilson; "Mapping ecosystem services: Practical challenges and opportunities in linking GIS and value transfer." Ecological Economics 60: 435-449 2006.

[28] Department of the Environment, Water, Heritage and the Arts; Interim Biogeographic Regionalisation of Australia Canberra 2008.

[29] New South Wales Department of Environment and Climate Change Sydney Basin Bioregion http://www.environment.nsw.gov.au/bioregions/ SydneyBasinBioregion.htm 2008.

[30] McDonald, R. C; Isbell, R.F; Hopkins, M.S; Walker, J; Speight, J.G Australian Soil and Land Survey Field Handbook Second Edition. Inkata Press Melbourne 1998. 
[31] McKenzie, N.J; Grundy, M.J; Webster, R; Ringrose-Voase, A.J; Guidelines for Surveying Soil and Land Resources CSIRO Publishing Canberra 2008.

[32] Isbell, R.F; The Australian Soil Classification CSIRO Canberra 2002.

[33] National Land and Water Audit; National Natural Resource Management Monitoring and Evaluation Framework http://www.nlwra.gov.au/nationalland-and-water-resources-audit/national-natural-resource-managementmonitoring-and-evaluati 2008.

[34] Department of Environment, Water, Heritage and the Arts; National Vegetation Information System http://www.environment.gov.au/erin/nvis /index.html 2008.

[35] Department of Environment and Heritage; Australian Vegetation Attribute Manual http://www.environment.gov.au/erin/nvis/avam/index.html 2003.

[36] National Parks Association of New South Wales; Community Biodiversity Manual National Parks Association of New South Wales Sydney 2002.

[37] Department of Environment and Heritage; AUSRIVAS http://ausrivas.canberra.edu.au/ 2008.

[38] Bureau of Rural Sciences; Australian Land Use Management Classification $B R S$ version 6 Bureau of Rural Sciences 2008.

[39] De Groot, R; Wilson, M.A; Boumans, R.M.J; "A typology for the classification, description and valuation of ecosystem functions, goods and services." Ecological Economics 41: 393-408 2002.

[40] Allen, J; Western Sydney Stakeholder Workshops Cooperative Research Centre for Irrigation Futures 2008.

[41] Sandhu, H; Ecosystem services in agricultural landscapes 14th Australian Agronomy Conference Australian Society of Agronomy Australia 2008.

[42] Wilson, M. A. \& Treg, C; Accounting for Ecosystem Services Associated with Agricultural Production in New Zealand http://ecovalue.uvm.edu/ newzealand/ 2006.

[43] Groenfeldt, D; Multifunctionality of Agricultural Water: Looking Beyond Food Production and Ecosystem Services FAO/Netherlands International Conference on Water for Food and Ecosystems The Hauge, International Network for Water and Ecosystem in Paddy Fields 2005.

[44] Molden, D; Tharme, R; Fujimoto, N; Amarasinge, P; Managing Irrigation for Multiple Ecosystem Services 4th World Water Forum Mexico International Water Management Institute 2006.

[45] Hawn, A; Ecosystem Farming: the Precursor of Markets in South Africa? http://ecosystemmarketplace.com/pages/article.news.php?component_id=7 43\&component_version_id=1246\&language_id=12. 2008.

[46] McDonald, D. $\bar{H}$ and Morrison, M; The Value of Habitat and Agriculture: non market valuation study of habitat and Agriculture in the Upper South East of South Australia Land and Water CSIRO Canberra 2005.

[47] Tamar Region NRM; Tamar Sustainability Index Final Report Tamar Region NRM Tasmania 2008.

[48] Rolfe, J and Prayaga, P; "Estimating values for recreational fishing at freshwater dams in Queensland" Australian Journal of Agricultural and Resource Economics 51: 2 pp 157-174 2007. 
[49] CSIRO Tropical Research Centre Valuing Tropical Ecosystem Services http://www.terc.csiro.au/vtres/case.asp 2008.

[50] Ecosystem Services project; The Goulburn Broken Catchment Victoria, http://www.ecosystemservicesproject.org/html/case_studies/goulburn.html 2008.

[51] Bohnet, I; Kinjun, C; Kroon, F; Sydes, D; Pert, P; Roberts, B; Community Uses and Values of Waters in the Tully-Murray catchment Far North Queensland NRM Ltd 2007. 